DOI: $\square$ https://doi.org/10.15407/techned2020.04.072

\title{
COMPONENTS OF MODEL FOR ANALYSIS OF INFLUENCE OF RENEWABLES ON THE ELECTRICITY MARKET PRICE IN UKRAINE
}

Journal

Publisher

ISSN

Issue

Pages
Tekhnichna elektrodynamika

Institute of Electrodynamics National Academy of Science of Ukraine 1607-7970 (print), 2218-1903 (online)

No 4, 2020 (July/August)

$72-75$

\section{Authors}

H.A. Ivanov ${ }^{1}$, I.V. Blinov ${ }^{2 \star}$, E.V. Parus ${ }^{2 \star \star}$, V.O. Miroshnyk ${ }^{2 \star \star *}$

1. State Company "Guaranteed buyer",

st. Simon Petlyury, 56, Kyiv, 03680, Ukraine,

e-mail: gennadiy_i@icloud.com

2- Institute of Electrodynamics National Academy of Science of Ukraine,

Peremohy ave., 56, Kyiv, 03057, Ukraine,

e-mail: blinovigor81@gmail.com; paruseugene@gmail.com; miroshnyk.volodymyr@gmail.com

* ORCID ID : https://orcid.org/0000-0001-8010-5301

** ORCID ID : https://orcid.org/0000-0001-9087-3902

*** ORCID ID : https://orcid.org/0000-0001-9036-7268

\begin{abstract}
The organizational basis and functions of the balancing group of the Guaranteed Buyer are considered as the main mechanism for implementing the state program to support the development of producers with renewable energy sources. The main advantages and disadvantages of such objects in terms of their influence on the pricing processes in organized segments of the electricity market of Ukraine are analyzed. The general approaches to solving problems arising in the face of increasing the share of electricity production from renewable sources in Ukraine are identified. Approaches to the means for analyzing the factors affecting the volumes supplied by stations with renewable sources on the pricing in organized segments of the electricity market of Ukraine are proposed. References 4, figure 1.
\end{abstract}


Key words: guaranteed buyer, renewable energy sources, electricity market, comparative analysis, simulation model.

Received: 28.02.2020

Accepted: 04.05.2020

Published: 26.06.2020

\section{References}

1. On Electricyty Market. The Law of Ukraine. 13.04.2017 No 2019-VIII. URL: http://zakon3.ra da.gov.ua/laws/show/2019-19

. (accessed: 29.04.2019). (Ukr)

2. On Alternative Energy Sources. The Law of Ukraine. 20.02.2003. No 555- IV. URL: https://z akon.rada.gov.ua/laws/show/555-15

. (accessed: 29.04.2019). (Ukr)

3. Butkevych O.F., Yunieieva N.T., Hurieieva T.M. On the issue of energy storages placement in the IPS of Ukraine. Tekhnichna Elektrodynamika. 2019. No 6. Pp. 59-64. (Ukr). DOI: https:// doi.org/10.15407/techned2019.06.059

4. Blinov I., Miroshnyk V., Shymaniuk P. Short-term interval forecast of total electricity generation by renewable energy sources producers. Pratsi Instytutu elektrodynamiky Natsionalnoi Akademii Nauk Ukrainy

2019. No 54. Pp. 5-12. (Ukr) DOI:

https://doi.org/10.15407/publishing2019.54.005 


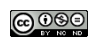

This work is licensed under a Creative Commons Attribution-NonCommercial-NoDerivatives 4.0 International License 